\title{
Deep Drilling for Groundwater in Bengaluru, India: A Case Study on the City's Over-Exploited Hard-Rock Aquifer System
}

\author{
Tejas Kulkarni ${ }^{1,2, *}$, Matthias Gassmann ${ }^{1}$, C. M. Kulkarni ${ }^{2}$, Vijayalaxmi Khed ${ }^{3}$ and Andreas Buerkert ${ }^{4}(\mathbb{D})$ \\ 1 Hydrology and Substance Balance, University of Kassel, 34125 Kassel, Germany; gassmann@uni-kassel.de \\ 2 Kiran Consultants, Bengaluru 560010, Karnataka, India; kulkarni@kiranconsultants.com \\ 3 Department of Agricultural Economics, University of Agricultural Sciences, \\ Bengaluru-UASB, Bengaluru 560065, Karnataka, India; vijayalaxmikhed39@gmail.com \\ 4 Organic Plant Production and Agroecosystems Research in the Tropics and Subtropics-OPATS, \\ University of Kassel, 37213 Witzenhausen, Germany; buerkert@uni-kassel.de \\ * Correspondence: tejas.kulkarni@uni-kassel.de
}

Citation: Kulkarni, T.; Gassmann, M.; Kulkarni, C.M.; Khed, V.; Buerkert, A. Deep Drilling for Groundwater in Bengaluru, India: A Case Study on the City's Over-Exploited Hard-Rock Aquifer System. Sustainability 2021, 13, 12149. https://doi.org/10.3390/ su132112149

Academic Editor: Hone-Jay Chu

Received: 6 September 2021

Accepted: 28 October 2021

Published: 3 November 2021

Publisher's Note: MDPI stays neutral with regard to jurisdictional claims in published maps and institutional affiliations.

Copyright: (c) 2021 by the authors. Licensee MDPI, Basel, Switzerland. This article is an open access article distributed under the terms and conditions of the Creative Commons Attribution (CC BY) license (https:// creativecommons.org/licenses/by/ $4.0 /)$.

\begin{abstract}
Over-exploitation of groundwater in India's fastest-growing metropolis, Bengaluru, has resulted in wells being bored to unprecedented depths in a crystalline-rock aquifer. However, key questions about sustainability of this extraction process remain unaddressed due to the complexity of monitoring. Using primary surveys, this study looks at the spatio-temporal evolution of the wells on a city scale, finding that catchments with deficient water infrastructure have deeper wells. To maintain yields, well with depths $>400 \mathrm{~m}$ are drilled, especially since 2000, leading to unsustainable groundwater extraction. Camera inspections in 54 wells at Electronic City in 2016 and 2017 revealed that water levels in the majority of the wells remained lower at depths $<100 \mathrm{~m}$, although some wells had deeper water levels at depths $>250 \mathrm{~m}$. Analysis of $\delta^{18} \mathrm{O}$ and $\delta^{2} \mathrm{H}$ signatures of groundwater samples at all depths followed the local meteoric water line indicating recent recharge, implying that drilling deeper only increases the borehole volume and does not tap into newer water sources. Water levels in deeper wells may stabilize at lower depths, are subject to high spatial variability, density of drilling, and high connectivity in upper zones. Given the interconnectedness between shallow and deeper aquifers, our research shows that increasing borewell depths could be a good indicator for falling aquifer water levels. This study fills an important gap in peri-urban, intermediate-scale aquifer conceptualizations across different land uses and provides further evidence for the difficulties of reliable groundwater monitoring in the over-exploited hard-rock aquifers of Bengaluru city.
\end{abstract}

Keywords: groundwater monitoring; Bengaluru; hard-rock aquifers; environmental isotopes; India

\section{Introduction}

Across Asia, growing urbanization puts pressure on groundwater resources, particularly in the cities of Delhi, Shanghai, Karachi, and Jakarta [1]. In developing countries, urbanization is often accompanied by a lack of urban water infrastructure and increasing water needs by peri-urban agriculture, resulting in an unsustainable use of groundwater [2]. Schwartz et al. [3] deplored the myths of groundwater sustainability in Asia that erroneously claim its use without depletion of aquifers. Gleeson et al. [4] suggested that, under such conditions, the governance of groundwater is more important for its sustainable extraction than resource depletion. Moreover, the debate on estimating the availability of groundwater resources based on recharge and management strategies can be traced back to Bredehoeft [5]. He argued that there is a great need to better understand groundwater capture based on an analysis of preferred flow paths to assess well recharge and productivity. In a recent review, Ferguson et al. [6] argued that investigations into the resource age (fossil/paleo-groundwater or modern/recent-groundwater) through environmental tracers may contribute to our understanding of how to bring groundwater resources back into balance while maintaining flows. In any case, groundwater management in the rural-urban 
transition zone of Asian megacities needs to be studied in a broader social-ecological context to effectively address challenges for a city's food, water, livelihood, and environmental security $[7,8]$.

With an estimated $250 \mathrm{~km}^{3}$ /year, India is the world's largest groundwater user [9]. The lack of conjunctive management and infrastructure, but also insufficient wastewater treatment, is blamed for the country's growing urban groundwater problem $[10,11]$. Moreover, in many cases, little is known about characteristics of the aquifers [12]. In particular, the hard-rock aquifers, which cover two-thirds of the country, are characterized by local heterogeneity whereby the role of preferential flow paths (due to fractures) for the capture and use patterns remain poorly understood $[12,13]$. In the peri-urban areas of the Deccan Plateau, over-exploitation of groundwater has led to the drying up of natural streams such as the Arkavathy River, adjacent to Bengaluru city [14-16]. Farmers in peri-urban areas were noted to dig deeper wells than in rural areas, with the backup plan of selling their lands if they run out of water $[17,18]$. However, hard data on the development of the groundwater table in the thousands of deep wells drilled over the last two decades are missing, and monitoring is limited to a few shallow wells, which are often disconnected from the real groundwater table $[19,20]$. Despite the government's campaign to ban new borewell drillings and a mandate to register existing borewells, the city continues to rely on its growing number of $\sim 500,000$ illegal wells, of which an unknown number are abandoned [21].

While it is well known that aerial electromagnetic surveys are useful to determine hydrological lineaments or characteristics of the aquifer in a region or catchment, they are often too expensive to be conducted. Similarly, individual well-logging is not feasible, unless it is community-driven [22-24]. Although community participation in groundwater governance and management is widely acknowledged to be beneficial, participatory groundwater programs typically cover only small areas and are limited to the small scale recovery of water tables with minimal leakage $[25,26]$. Hence, the effectiveness of such interventions depends on their ability to improve the performance of closed-loop systems. However, major fluctuations in water levels in wells within small areas are noticed in periurban Bengaluru, prompting the recommendation of periodic camera inspections in wells rather than standard electrode readings to better understand flow paths [20,27]. Essentially, decision support systems for groundwater governance on intermediate scales, such as the peri-urban areas, would require local and intermediate-scale aquifer characterizations [28].

In view of the above, the goal of this study was to use borewell drilling data collected from several sources to analyze the water table development of Bengaluru city across several decades. We evaluated the aquifer characteristics on an intermediate scale in an industrial peri-urban land-use cluster in the city using borehole cameras. Thereafter, stable water isotope analysis was utilized to understand the flow of the groundwater in these wells. We review prior hydrogeological conceptual models to identify and report on critical processes in two peri-urban regions that have a significant impact on monitoring issues, and the results are presented in light of long-term sustainability of groundwater extraction.

\section{Materials and Methods}

Bengaluru is situated at an altitude of $960 \mathrm{~m}$ on the South Indian Deccan Plateau (Figure 1a) and receives an average annual rainfall of $860 \mathrm{~mm}$ [15]. The metropolitan can be divided into six sub-catchments: the Upper Arkavathy Catchment (UAC) and the Vrisbhavathy Catchment (VVC), which are tributaries to the Arkavathy river on the western side of the city; and the Yellamallappa Chetty (YMC) Valley, Western Hoskote Catchment (WHC), the Kormangala-Challaghatta Catchment (KCC), and the Bommansandara-Attibele Catchment (BAC), all of which flow into the South Pinnakini river on the eastern side of the city (Figure 1b). The underlying geology consists of fractured granites, into which boreholes down to $400 \mathrm{~m}$ have been drilled. 


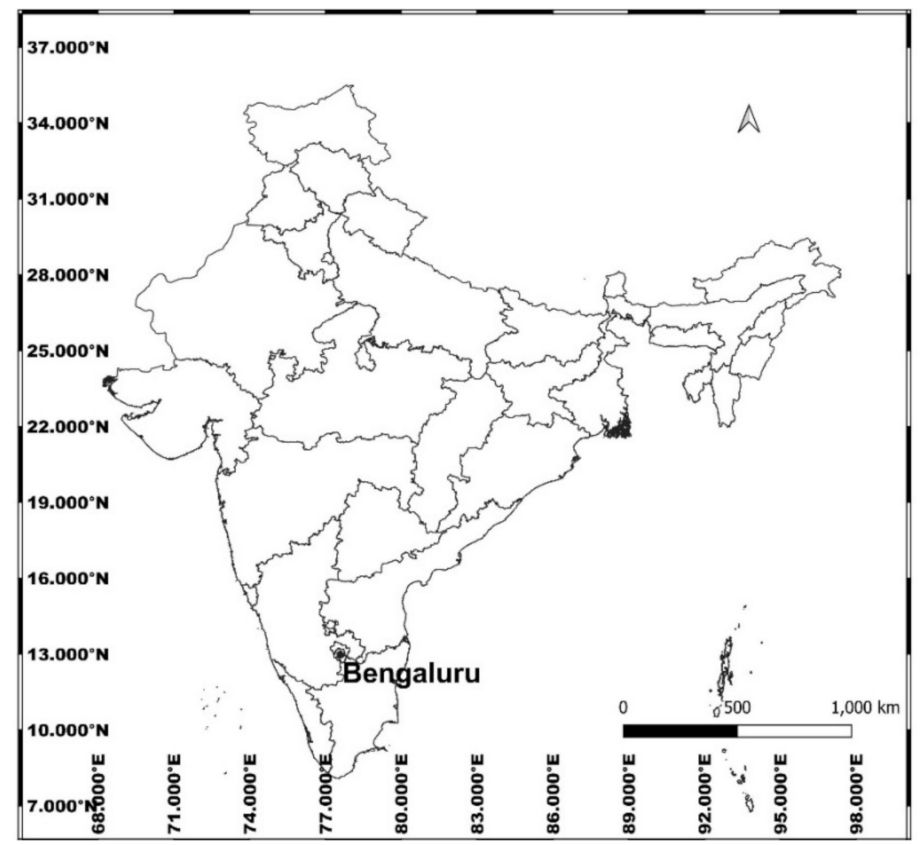

(a)

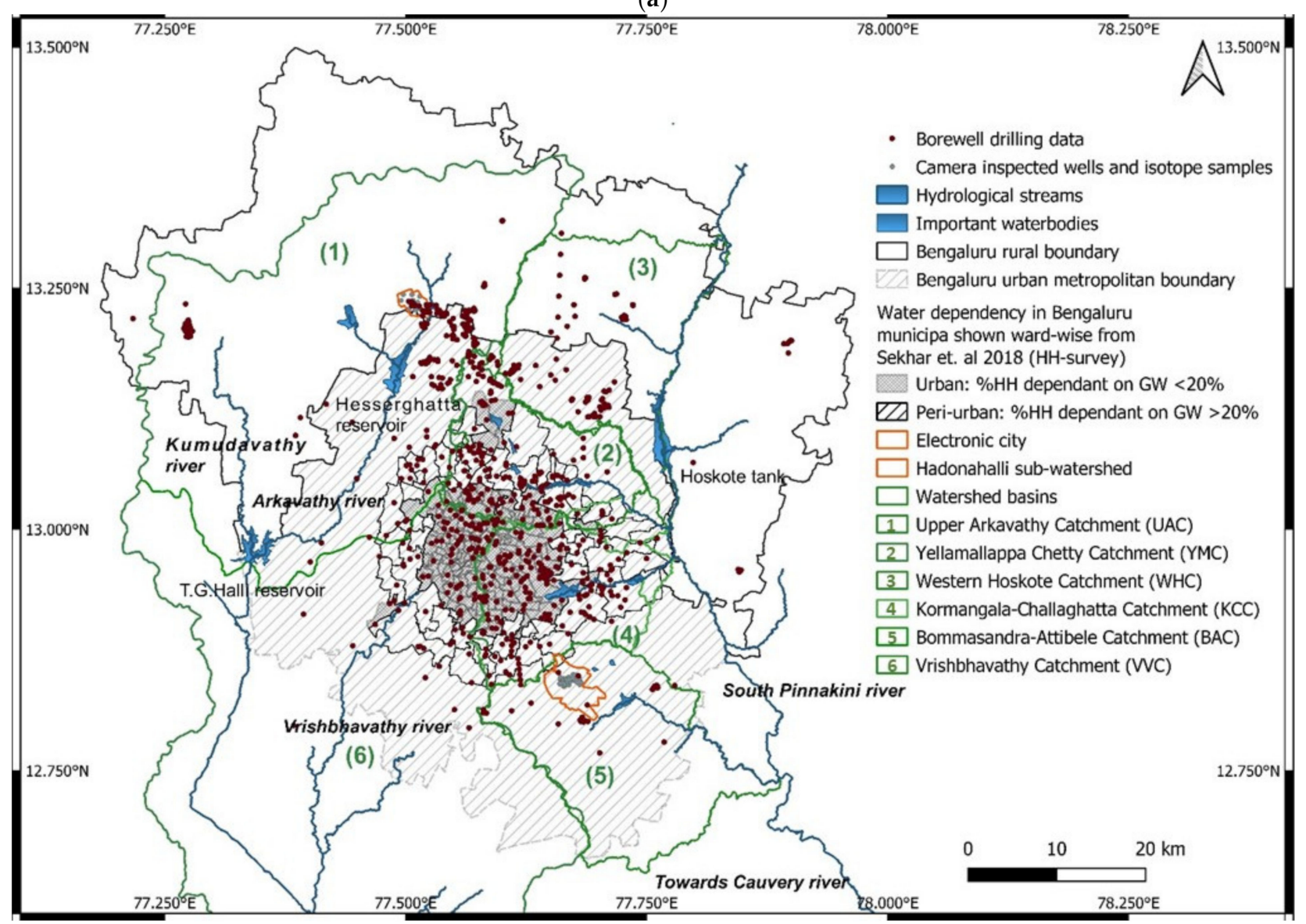

(b)

Figure 1. Location of Bengaluru, India (a); hydrological catchments and boundaries of Bengaluru city region (India) and data used in the study $(\mathbf{b})$. 


\subsection{Reproducing Historical Groundwater Table Development of Bengaluru City}

Primary data from well logs collected by local hydrogeological consultants, farmers and borewell drillers were used to determine well depths and water levels on the city scale over time [29-31]. Data comprised drilling depth, position (GPS/addresses), date, recorded static water level, and pumping yield. While the collected data may be subject to some uncertainty, its comprehensive nature allows for solid conclusions. Altogether, the dataset comprised 1303 well depths, 640 water levels and 630 borewell yields (Supplementary Materials-Primary Survey Well Depths).

We overlaid the well location data and the Cartosat digital elevation model (DEM), available in the 'Bhuvan' portal of the National Remote Sensing Centre (NRSC), to obtain the surface elevation of the borewells in a GIS environment. We thereby spatially divided the dataset according to the six major surface water catchments delineated from the DEM and overlaid Bengaluru's administrative boundaries, such as the municipal, metropolitan (urban district) and rural boundaries. We further intersected the households' groundwater usage (shown ward-wise) and water supplied by piped water from Sekhar et al. [32]. From this, we chose areas (wards) in which more than $20 \%$ of the households depend on groundwater, as a part of the peri-urban divide for further analysis (Figure 1b). Trend analysis for the medians of yearly data at 10-year periods was performed as defined by Hirsch and Slack [33] using the Mann-Kendall trend test (MK) included in the Regional Kendall test (RK) package in R. Therefore, the Kendall's tau value of the MK trend test shows the increasing $(\tau>0)$ or decreasing trend $(\tau<0)$ at a $95 \%$ confidence level, and the magnitude of trend is given by the Sen's slope. A $p$-value of $<0.05$ shows the existence of a monotonic trend. Further, we interpolated the most densely populated areas for the urban and peri-urban transects using the inverse-distance weighting nearest neighborhood method (IDW-NN) in QGIS [34].

\subsection{Aquifer Characterization through Hydrogeological Investigations by Camera Inspection}

For comparative assessment, we considered Ballukraya and Srinivasan's [20] theories of identifying wells suitable for long-term monitoring, namely, those with yielding fractures below static water levels. We inspected 54 wells with a camera in the Electronic City (EC) township (Figure 2) [15,35]. Electronic City covers an area of $3.3 \mathrm{~km}^{2}$ and forms an integral part of the rural-urban interface between the municipal and urban district boundary in ridges of the BAC valley. It receives water from a piped supply since 2008, but the borewells which are operational are still being pumped to meet local demands. EC has its own municipality, which is bolstered by bottom-up approaches to long-term water management and strictly enforces the ban on drilling further wells [36,37]. We took note of the well drilling depths, static water levels measured, depth of casing pipes, submersible pumps, yielding and dry fracture depths, and other well obstructions and plotted visualizations of the aquifer structure (Figure A1 in Appendix A; Supplementary Materials S2-Camera Well Logs, Sheet 2). There are four lakes within the sub-catchment, which undergo bed-silt removal, likely leading to increased recharge. The 54 investigated wells are located in a $2.1 \mathrm{~km}^{2}$ sub-catchment of the Hebbagodi Lake, which has an industrial land use in the South of Bengaluru, as compared to the northern agricultural sub-catchment of Ballukraya and Srinivasan [20].

Camera data were collected during a monitoring campaign in January 2016 and February 2017. In order to cluster the wells based on depths, we used the cluster package in $\mathrm{R}$ to do k-means clustering $(\mathrm{k}=3)$ and create a hierarchical cluster dendrogram based on the ward method [38]. 


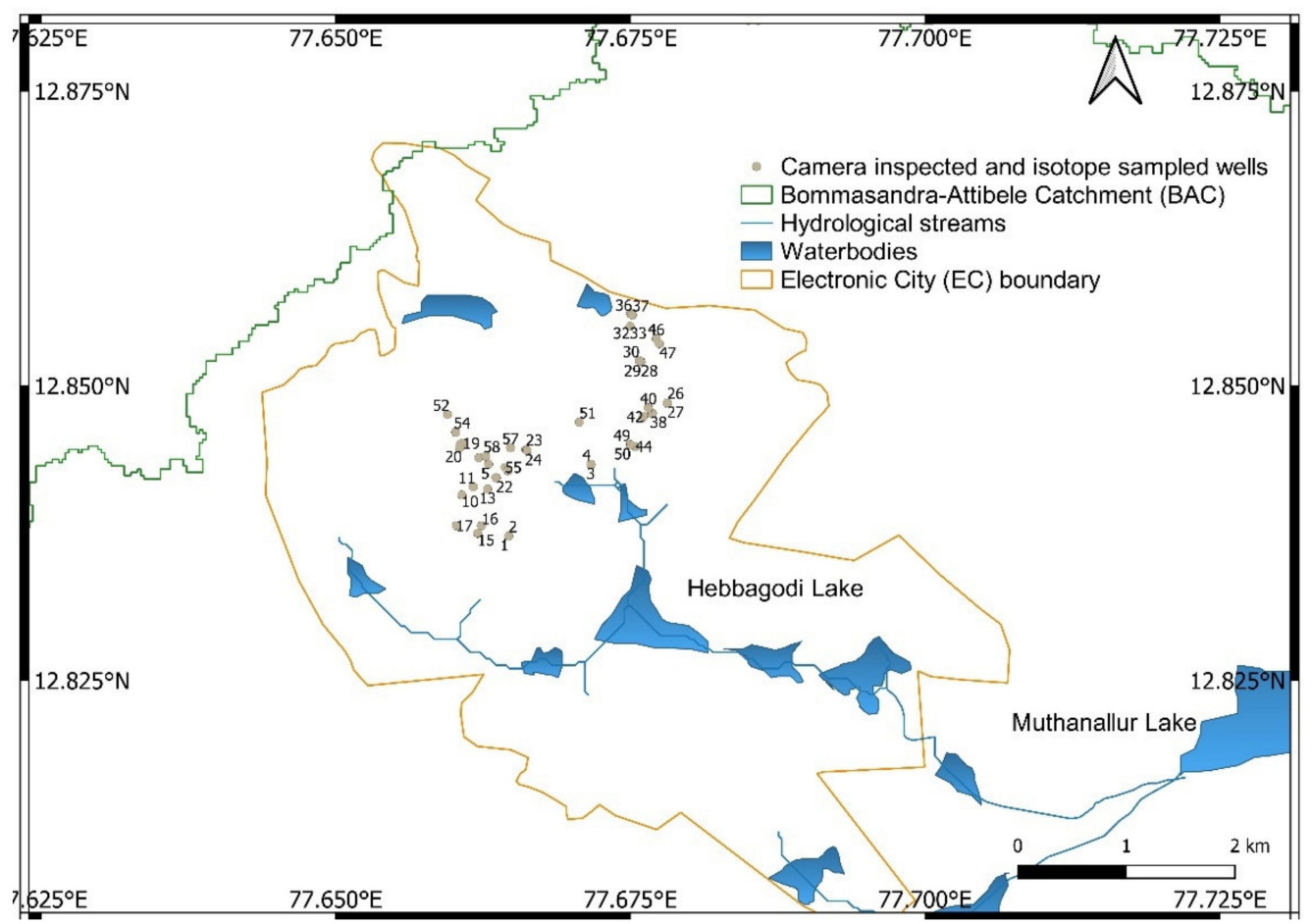

Figure 2. Location of camera-inspected wells in Electronic City of Bengaluru, India.

\subsection{Hydro-Geochemical Investigations Using Stable Isotopes}

Phase transitions cause changing signals in water isotopes, which help interpret runoff generation processes and seepage dynamics $[39,40]$. We collected water samples in 41 of the camera-inspected wells and the four lakes within a sub-catchment adjoining the ridge of the BAC valley in Electronic City during April 2021. In the UAC, the sampling strategy accounted for the camera-inspected wells from previous studies [20,41]. In February 2020, five samples of surface water (tanks), and 16 wells were collected in the Hadonahalli sub-catchment of UAC. Rainfall isotope data (79 samples) collected between 2017 and 2018 were taken from secondary sources [27,41] (Supplementary Materials S3). During the pumping and sampling collection, it was noted that in many cases the borewell 'sucks air' or 'lags', before beginning to yield water again. Hence, we collected the recharged pumped water to assess the isotope signatures. All water samples were analyzed for the stable isotopes ${ }^{18} \mathrm{O}$ and ${ }^{2} \mathrm{H}$ using cavity ring-down spectroscopy (PICARRO L2130-I, USA at the University of Kassel). Stable isotopes are reported as $\delta^{18} \mathrm{O}$ and $\delta^{2} \mathrm{H}$-that is, as deviation from Vienna Standard Mean Ocean Water (VSMOW). For comparative reasons, the Global Meteoric Water Line (GMWL) derived by Dansgaard [42] and the Regional Meteoric Water Line (RMWL) for South India reported by Kumar et al. [43] were used.

\section{Results and Discussions}

\subsection{Spatio-Temporal Trends in Borewell and Groundwater Table Depths in Bengaluru City}

Bengaluru's borewells are currently drilled to a maximum depth of $430 \mathrm{~m}$ (Figure 3a). Taken together, the collected data show that borewell drilling depths have steadily increased for the past 20 years. The majority of the recorded static water levels, on the other hand, remain at lower depths ranging from $10 \mathrm{~m}$ to $60 \mathrm{~m}$. This could be due to the accumulation of water in the shaft during the drilling process. More significantly, recorded borewell yields have not increased, while borewell depth has (Figure 3b). This means that drilling deeper wells did not boost well functionality or tap into newer fracture zones, but rather aims at sustaining water yields. The reason could be that the well's storage ability for percolating water is improved in deeper wells. This confirms that drilling deeper is not a sustainable 
way of accessing groundwater, since borewell depth has to be steadily increased to fetch the same amount of water [18].

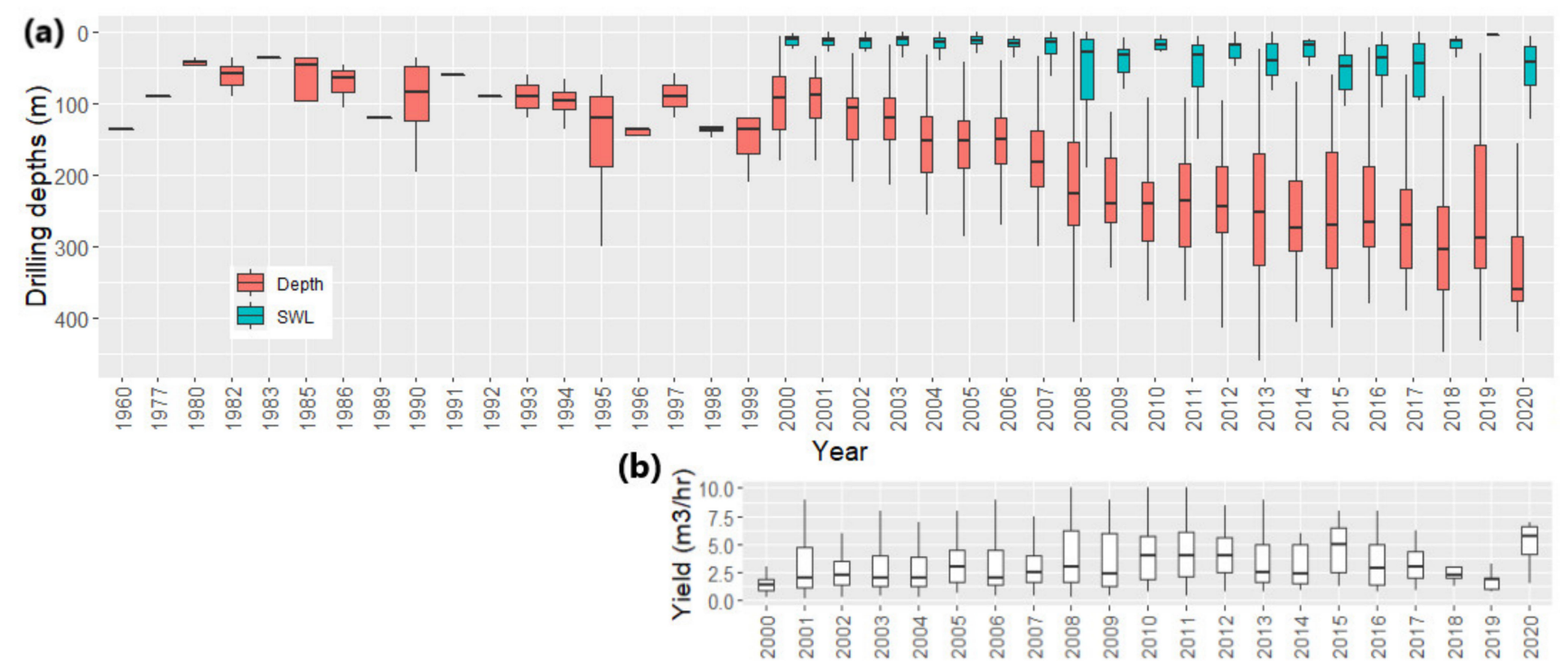

Figure 3. Temporal evolution of drilling depths (m) and reported Static Water Levels (SWL) (m) in the Bengaluru region, India (a). Temporal evolution of reported borewell water yields in $\mathrm{m}^{3} / \mathrm{h}(\mathbf{b})$.

In the two decades following the year 2000, median drilling depths increased, whereby this pattern was more pronounced in the peri-urban and rural transects (Table 1). This matches well with the more poorly developed pipeline infrastructure for water supply and the higher dependency on groundwater in these areas as shown by Goldman and Narayan [44]. The lower median depths and groundwater levels in the urban and southern catchments (KCC and VVC) may be partly explained by anthropogenic recharge due to wastewater discharge and supply pipeline leakage [45]. On the other hand, because the southern catchment of BAC lacks water supply infrastructure, the associated drilling depths were larger. The catchments of UAC and WHC in the northern part of Bengaluru have relatively deeper drilling depths than the YMC, which has better infrastructure [46,47].

Table 1. Spatio-temporal distribution of median drilling depth, static water levels and reported yield in Bengaluru, India. (UAC-Upper Arkavathy Catchment; YMC - Yellamallappa-Chetty Catchment; WHC_Westerm Hoskote Catchment; KCC—Kormangala-Challaghatta Catchment; VVC_Vrishbhavathy Catchment; BAC_Bommasandara-Attibele Catchment; NA—no data available).

\begin{tabular}{|c|c|c|c|c|c|c|c|c|c|c|}
\hline \multirow{3}{*}{ Parameter } & \multirow{3}{*}{ Time Period } & \multicolumn{9}{|c|}{ Location Category } \\
\hline & & \multicolumn{3}{|c|}{ Spatial } & \multicolumn{6}{|c|}{ Valleys } \\
\hline & & Urban & Peri-Urban & Rural & UAC & YMC & WHC & KCC & VVC & BAC \\
\hline \multirow{3}{*}{$\begin{array}{l}\text { Drilling depth } \\
\text { of borewells } \\
\text { (m) }\end{array}$} & Pre-2000 & NA & 120.1 & 105.1 & 120.1 & 63.1 & 105.0 & NA & NA & 115 \\
\hline & 2000-2010 & 125 & 152.2 & 180.2 & 180.2 & 141 & 195 & 140 & 83 & 152 \\
\hline & $2011-2020$ & 211 & 264.6 & 301.8 & 300 & 261.3 & 300 & 198 & 188 & 331 \\
\hline \multirow{2}{*}{$\begin{array}{l}\text { Static water } \\
\text { levels }(\mathrm{m})\end{array}$} & 2000-2010 & 12 & 15.0 & 23.8 & 15 & 43.3 & 50 & 15 & 18 & 13 \\
\hline & 2011-2020 & 18 & 29.0 & 46.4 & 36 & 35 & 38 & 15 & 16 & 76 \\
\hline \multirow{2}{*}{$\begin{array}{c}\text { Reported } \\
\text { yield } \mathrm{m}^{3} / \mathrm{h}\end{array}$} & 2000-2010 & 2.45 & 2.0 & 4.0 & 2.0 & 2 & 2.0 & 2 & 2 & 3.2 \\
\hline & $2011-2020$ & 3.5 & 4 & 3.9 & 2 & 2.75 & NA & 3.4 & 3.5 & 3.5 \\
\hline
\end{tabular}


The drilling slopes, i.e., the rise in drilling depth over time, in the rural and peri-urban areas were 16.9 and $15.4 \mathrm{~m} /$ year, respectively, from 2000 to 2010 (Table 2). The slope of $12.3 \mathrm{~m} /$ year (2010-2020) in the drilling depths of the peri-urban areas agrees well with Sekhar et al. [32], who estimated a 10-12 m decline in groundwater levels between 2016 and 2017 in 154 wells, even though the authors explained this drop by lower rainfall amounts in 2017. Between 2000 and 2010, the slope of drilling depths was steepest, ranging from $4.8 \mathrm{~m} /$ year to $17.1 \mathrm{~m} /$ year. In the next decade, slopes in drilling depths decreased in the northern catchments, the rural areas, and the peri-urban zone. There was no significant trend detected in the southern catchments of VVC and BAC. This may be explained by unequal distribution in the water supply pipeline in Bengaluru after 2010 and the increased return-flow recharge in the southern catchments [16,32,47,48].

Table 2. Results of the Mann-Kendall trend test (Sen's slope) for rise in borewell depths in Bengaluru, India. n.s.- not significant ( $p \geq 0.05)$; NA—no data available.

\begin{tabular}{|c|c|c|c|c|c|c|c|c|c|c|}
\hline \multirow{3}{*}{ Parameter } & \multirow{3}{*}{ Time Period } & \multicolumn{9}{|c|}{ Mann-Kendall Trend Analysis-Sen's Slope } \\
\hline & & \multicolumn{3}{|c|}{ Spatial } & \multicolumn{6}{|c|}{ Valleys } \\
\hline & & Urban & Peri-Urban & Rural & UAC & YMC & WHC & KCC & VVC & BAC \\
\hline \multirow{4}{*}{$\begin{array}{c}\text { Rise in } \\
\text { drilling depth } \\
\text { of borewells } \\
\text { (m/year) }\end{array}$} & Pre-2000 & NA & 3 & 6 & 7 & NA & 3.30 & NA & NA & NA \\
\hline & $2000-2010$ & 13.0 & 15.4 & 16.9 & 17.1 & 4.9 & 13.5 & 15.4 & 12 & 11.25 \\
\hline & $2011-2020$ & 5.6 & 12.3 & 7.5 & 6.1 & 8.5 & 2.6 & 4.2 & n.s. & n.s. \\
\hline & $1960-2020$ & 10.7 & 7.4 & 9.0 & 9.3 & 8.0 & 7.1 & 8.3 & 8.5 & 9.70 \\
\hline
\end{tabular}

The spatial interpolation revealed an overall increase in well depth, even in urban areas, from 2000 to 2010 (Figure 4a,b). Deeper wells in metropolitan areas were found in the wards with the largest household water usage, as illustrated by Mehta et al. [48]. However, it must be noted that there is substantial spatial heterogeneity within the borewell depth dataset of one decade. Thus, the interpolated values do not represent the real groundwater surface of the corresponding decade.

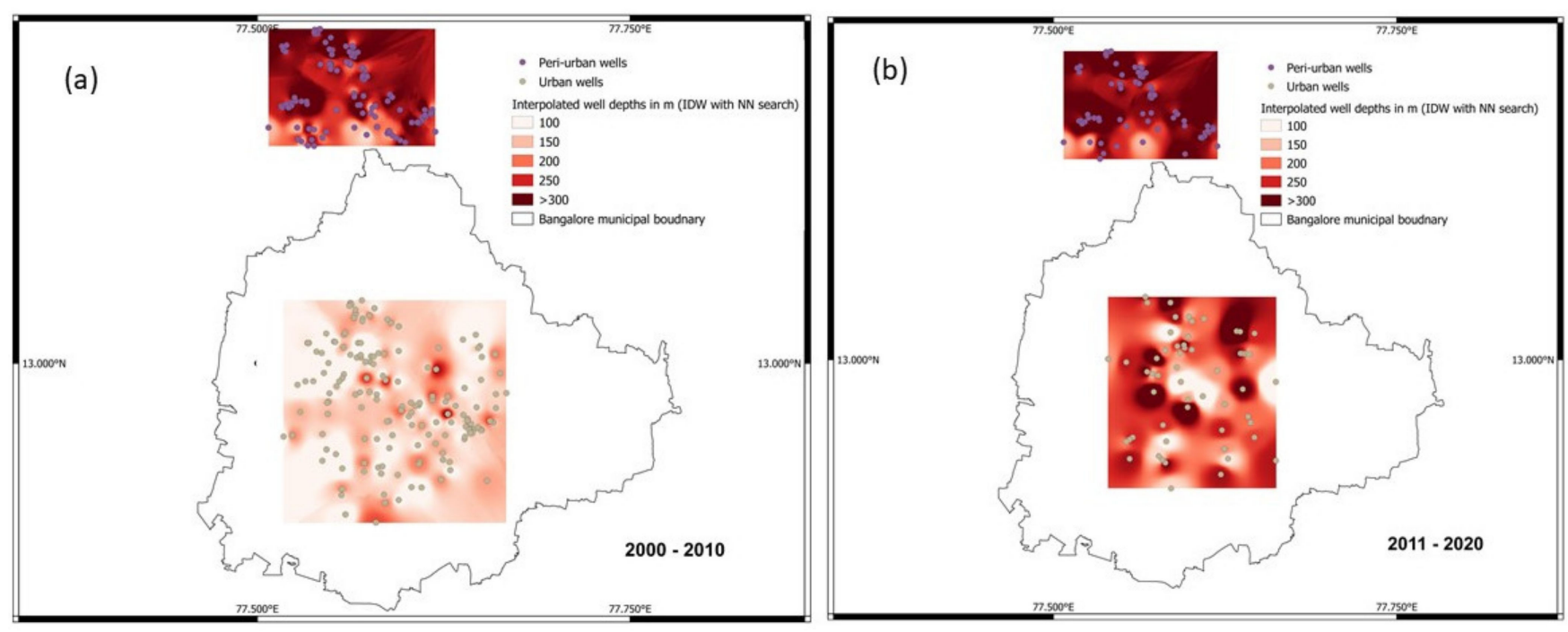

Figure 4. Spatial interpolation through IDW-NN of well depths in meters below ground level (m.bgl) for urban and peri-urban transects of Bengaluru, India, (a) 2000-2010 and (b) 2011-2020.

\subsection{Aquifer Conceptualization at Electronic City, Bengaluru}

Electronic City lies in the BAC catchment, which experienced an average rise in drilling depths of $9.7 \mathrm{~m}$ /year between 2000 and 2020 (Table 2), representing the highest increase in drilling depth of all catchments. The results of the clustering based on drilling 
depths yielded three clusters: type-A wells with depths of $56 \mathrm{~m}-112 \mathrm{~m}$ (19 wells), type-B wells with depths of $120 \mathrm{~m}-246 \mathrm{~m}$ ( 25 wells), and type-C wells with depths of $300 \mathrm{~m}-435 \mathrm{~m}$ (10 wells; Figure 5). The results of the camera inspection in the wells revealed that $20 \%$ of all the fractures occurred at $15 \mathrm{~m}-30 \mathrm{~m}$ and $94 \%$ of the fractures lie at $0 \mathrm{~m}-240 \mathrm{~m}$ (Figure A2). The clustering adequately reflected the observed fracture zones across depths in the wells. In order to understand the vertical flow in the aquifer rather than the lateral flow in the systems, the camera inspections of 54 wells in EC were plotted along with the fractures and static water levels (Figure A1).

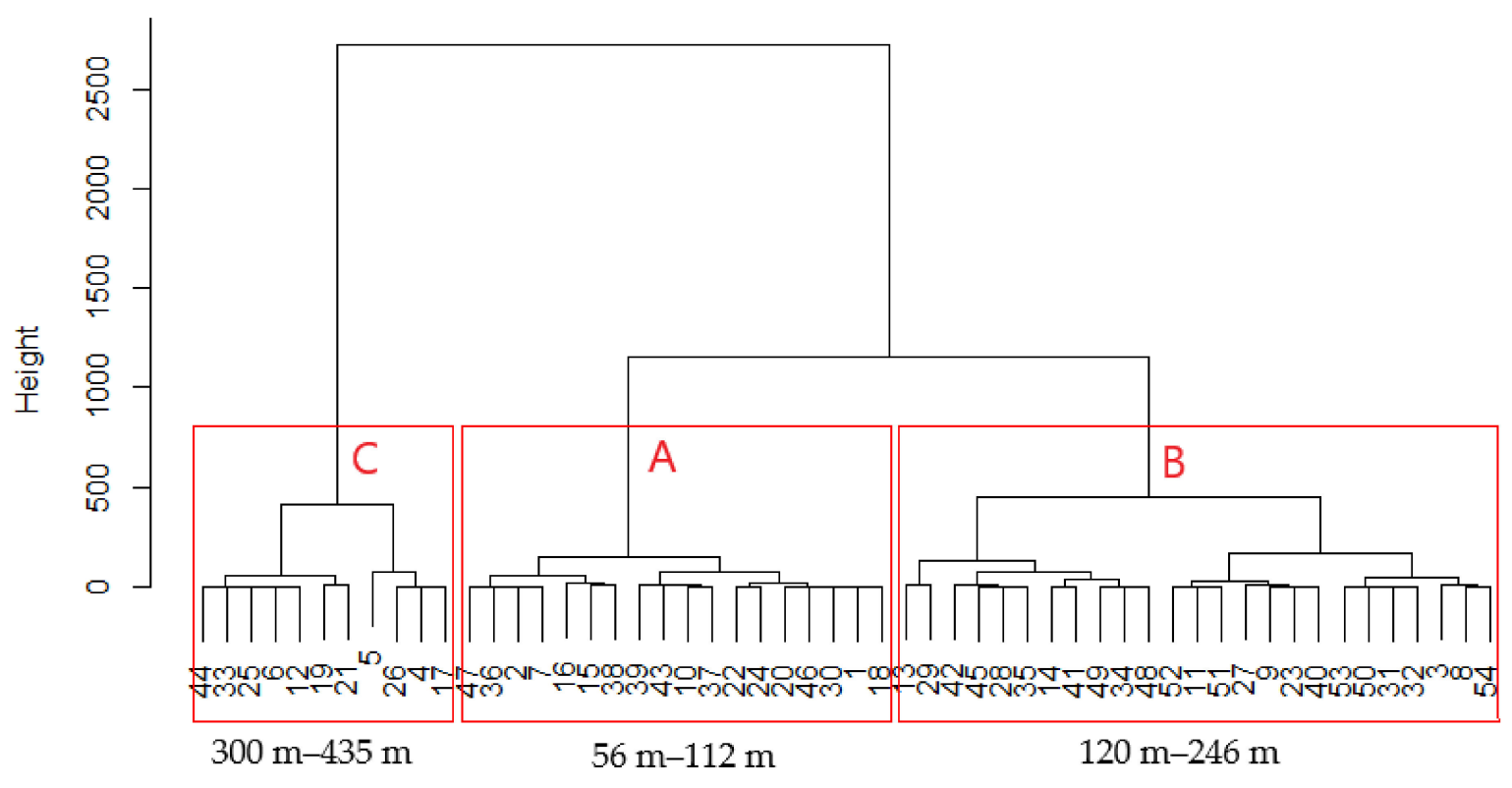

Figure 5. Cluster analysis of wells based on depths in Electronic City, Bengaluru (India) using the ward method.

The water levels in the wells are also influenced by the fractures, which differed spatially and across depth. The static water levels in the type-A wells remained at $10 \mathrm{~m}-30 \mathrm{~m}$. To facilitate well recharge, typically, borewells are lined with a casing of mild-steel, galvanized iron, or perforated plastic pipes up to a depth of $30 \mathrm{~m}$ and have a diameter of 11 to 16 $\mathrm{cm}$. Similarly, 22 of the 25 type-B wells showed static water levels at depths of $10 \mathrm{~m}-90 \mathrm{~m}$. The camera visuals revealed the cascading flow of water from the upper yielding fractures into the borewells, indicating recent recharge of water. The water levels in these wells stabilized at lower depths $(70 \mathrm{~m}-110 \mathrm{~m})$, owing to the collected stocking up of water from the upper yielding aquifers. In type-C wells, we also noted that groundwater levels decreased with increasing depths of wells in EC but were mostly dependent on the yielding fractures (Figure A3). For example, well 4, which is $390 \mathrm{~m}$ deep and has only one fracture at a depth of $42 \mathrm{~m}$, had a lower static water level at $284 \mathrm{~m}$ than well 26, which was also $390 \mathrm{~m}$ deep but had multiple fractures at various depths and a static water level of $70 \mathrm{~m}$. Similarly, well 5 (437 m deep), which is $30 \mathrm{~m}$ apart from well 4 , had lower static water levels in 2016, with $327 \mathrm{~m}$. Wells 25 and 26, which are $25 \mathrm{~m}$ apart, had identical fracture zones at different depths, showing spatial homogeneity. While the water levels in both wells were similar in 2016, we noticed that, when well 26 started pumping in 2017, the water levels in well 25 dropped by a hundred meters. Well 26 and 3 had six and three yielding fractures in both years, while the stagnant water level measurements in well 5 and 17 rose by $100 \mathrm{~m}$ in 2017, with two yielding fractures at depths $>90 \mathrm{~m}$. Collins et al. [27] pointed out that groundwater levels in the fractured crystalline aquifer can fluctuate dramatically depending on rainfall. It is also important to note that recharge not only occurs through rainfall, but also through the gardening and recharge-wells in many campuses and broken water infrastructure. The camera inspections in combination with the clustering confirmed the existence of three types of wells for an urban part of Bengaluru, first proposed by Ballukraya and Srinivasan [20] for rural Bengaluru (Figure 6). We observed that six out 
of the 10 type-C wells had yielding fractures below water levels for both years and could therefore be selected for further groundwater monitoring (Table A1).

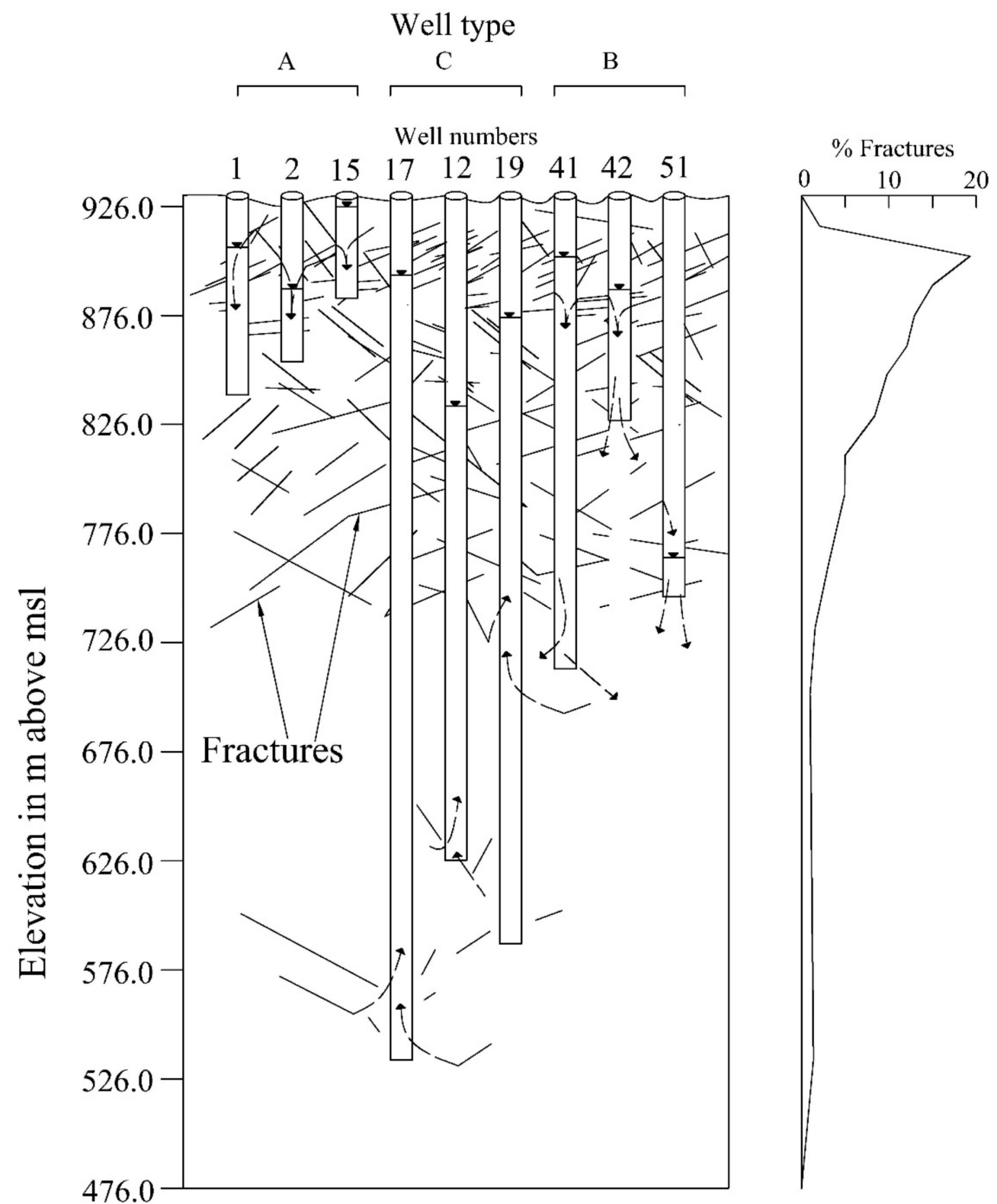

Figure 6. Conceptual aquifer of Electronic City, Bengaluru, India, based on camera inspections shown as elevation in meters above mean sea level (msl).

Although the deeper zones of the aquifer have fewer fractures and higher connectivity is found only in the upper zones, extensive groundwater extraction has resulted in increased vertical connectivity through cascading flows. Thus, stabilized water levels in the wells do not represent traditional water tables or saturation levels, as found in porous aquifers [20,27]. Over-extraction of groundwater, on the other hand, has caused a long-term annual decline in water tables in certain peri-urban regions. For example, in the BAC, Yadav et al. [49] reported a $5 \mathrm{~m}-7 \mathrm{~m} /$ year drop in the water table. Similarly, the water table in the peri-urban regions of the nearby Kormangala-Challaghatta (KCC) valley declines at a rate of $10 \mathrm{~m}$ per year [32,45]. While these estimates differ, it appears that an average $9.7 \mathrm{~m} /$ year increase in borewell depth may be a valid predictor of the decrease in groundwater table, despite the fact that this will strongly vary, reflecting significant heterogeneity and preferred flow pathways. Moreover, Chandrakanth [50] observed that 
local hydrogeologists, also known as water-diviners and well-drillers, have the tendency to drill deeper than necessary to improve groundwater access to users.

On the brighter side, the high connectivity across depth suggests that groundwater conservation and managed aquifer recharge may help restore and maintain groundwater tables. Even though 2016 was a drought year with only $810 \mathrm{~mm}$ of rainfall compared to $1621 \mathrm{~mm}$ in 2017, water levels in the EC wells did not change significantly. This is consistent with the findings of Sekhar et al. [32], who argued that in both built-up and agricultural land, larger floods and insufficient storm water management result in enhanced recharge during monsoons via indirect pathways such as lakes, recharge pits, and abandoned borewells, resulting in higher water tables. Several studies have demonstrated the benefits of rainwater harvesting projects such as the "one million recharge wells", which, however, has its own debate on the direct or indirect effects of aquifer recharge [37,51,52]. In any case, in the long-term water level monitoring, water stockpiling must be taken into account.

\subsection{Hydro-Geochemical Analysis of Stable Isotopes in Water}

Given that most of the type- $C$ wells receive water from yielding fractures below the SWL at a depth $>245 \mathrm{~m}$, the question of whether this water is recently recharged water or consists of paleowater remains important. The $\delta^{18} \mathrm{O}$ isotopic concentration of groundwater samples ranged from $-4.38 \%$ to $-2.01 \%$, and the $\delta^{2} \mathrm{H}$ concentrations from $-27.3 \%$ to $-15.4 \%$, whereby variation in isotope signatures varied little with bore well depth (Figure $7 \mathrm{a}, \mathrm{b}$ ). Previous studies mention high temporal consistency in isotopic signatures due to the fractured aquifers' high connectivity and mixture $[39,40]$. This might explain the small variation in isotope signals in the type-B wells of our groundwater samples and the general similarity across depths. Seasonal variations of $\delta^{2} \mathrm{H}$ and $\delta^{18} \mathrm{O}$ values in rainfall are high in Bengaluru (Figure 8), as they depend on event-specific rainfall amounts, which are even projected to become more erratic in the future [53]. All isotopic signals of groundwater samples collected in this study fall within the range of rainfall samples and are located at or below the Regional Meteoric Water Line [42] in the dual isotope plot, which indicates recent recharge with little evaporation. Moreover, this is also supported by the fact that groundwater signatures of both the UAC and the BAC catchment fall well within the range of rainfall signatures (Figure A4).

If the groundwater pumped from the aquifer was fossil, stable water isotope signatures above the meteoric water line could be expected, as shown by Kumar et al. [54] for Tamil Nadu, India, or as generalized by Wenninger [55] for the whole of India. This is supported by Singh et al. [56], who used a systematic approach to select and filter well samples using environmental isotopes such as ${ }^{18} \mathrm{O}$ and radiogenic isotopes such as ${ }^{3} \mathrm{H}$ and ${ }^{14} \mathrm{C}$ to estimate groundwater age and characterized modern age water in most of the wells in the adjoining KC valley. To obtain further information about the 'real' groundwater, we recommend sampling from the type-C wells in EC (Table A1), which have yielding fractures below the SWL, and thus might be representative for deep groundwater. While our stable isotope studies indicate that current rainwater plays a dominant role in groundwater recharge in Bengaluru's wells across depths, it cannot be excluded that paleo groundwater played a role in the past. It may be well possible that all paleo-groundwater has been extracted in previous decades, resulting in, as Ramesh [57] describes, "cities that are already living in permanent day zero conditions". On the other hand, the recent recharge would allow for a sustainable management of the groundwater resources, which was not the case in the last decades. Long-term groundwater management should therefore aim to decrease the rise in drilling depths, which leads to increased well abandonment, while also maintaining the quality and quantity of groundwater [6]. 


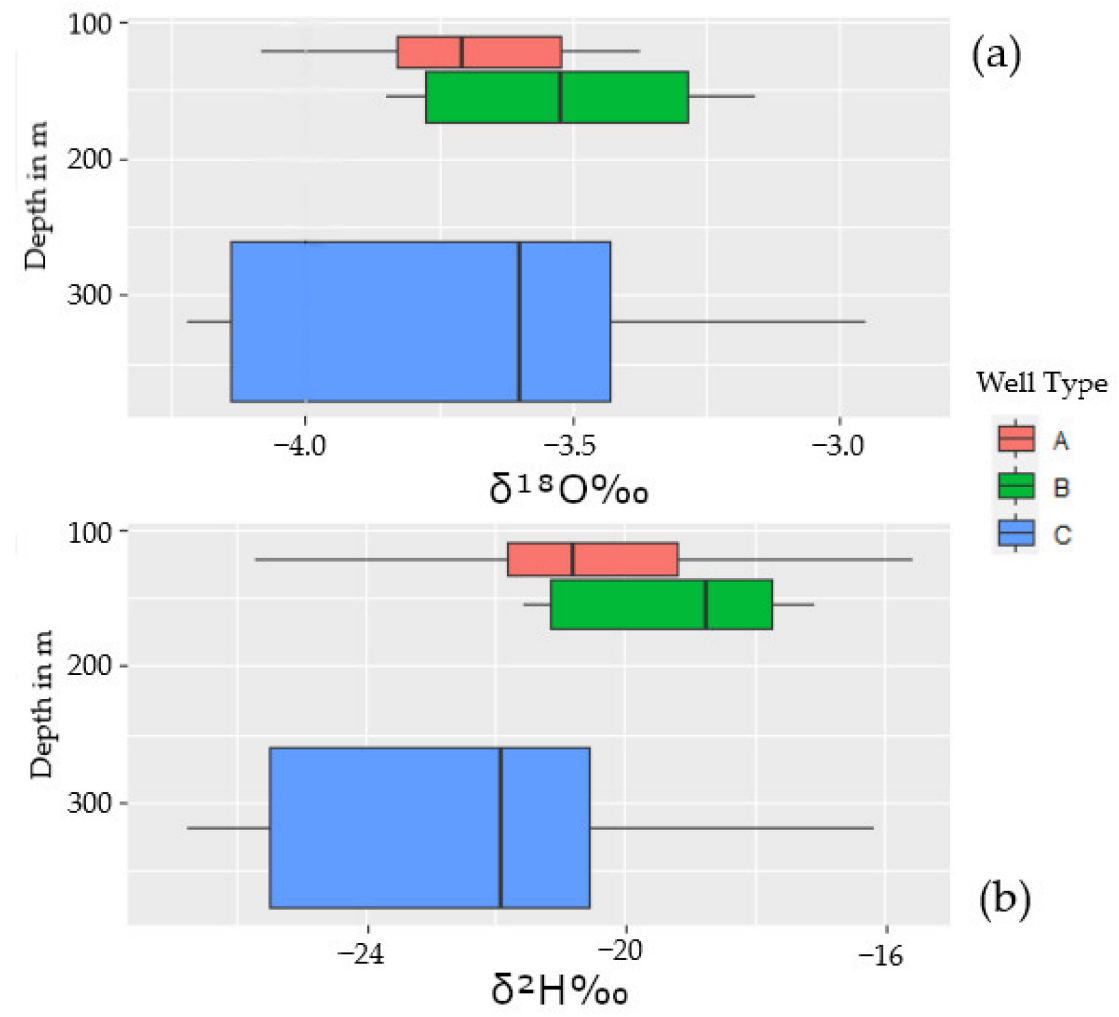

Figure 7. (a) Stable isotope concentration of $\delta^{18} \mathrm{O} \%$ samples from borewells in Bengaluru, India, in different depths. Groundwater values do not seem to have a variation across depth. (b) Stable isotope concentration of $\delta^{2} \mathrm{H} \%$.

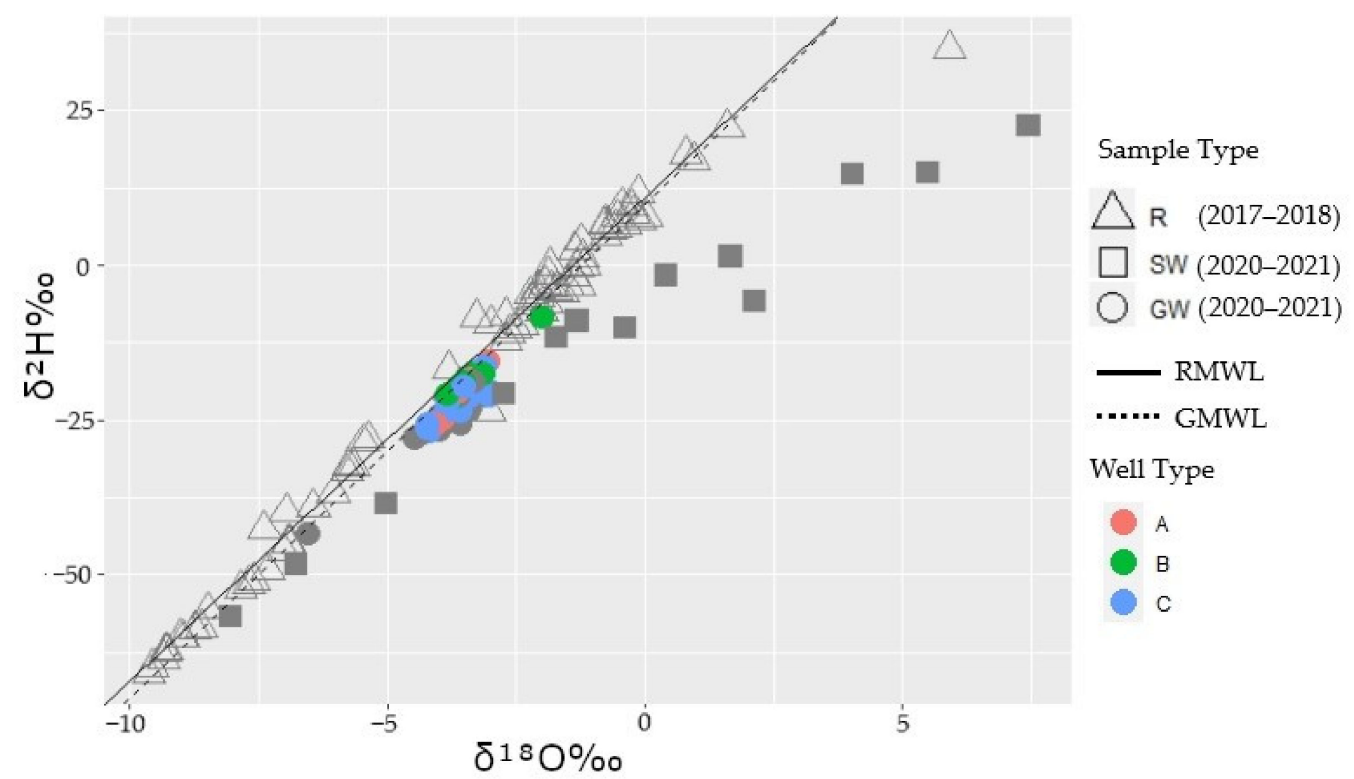

Figure 8. Dual isotope plot of rainfall (R), surface waters (SW) and groundwater (GW) samples against the regional meteoric water line by Kumar et al. (2010) and the global meteoric water line given by Dansgaard (1964).

\subsection{Strengths and Limitations of the Study}

The dataset used in this study consists of the largest number of bore well data used for groundwater table analysis in this region. However, even the more than 1300 borewells included here only represent a very small amount $(<1 \%)$ of the existing borewells in and 
around Bangalore. Still, we argue that the main characteristics of the borewell evolution of the region are captured in our dataset, since the dataset covers a large area, significant trends could be detected and the heterogeneity typical for hard-rock aquifers is included in the camera inspections. However, given the aquifer's high connectivity and the complex indirect recharge process, we must keep in mind that the findings cannot be generalized into land-use-based lateral boundaries in such dynamic peri-urban transitions. While the study offered solid information on well selection for future monitoring, it did not allow to collect data on seasonal variations in water levels in the wells. Although the isotopic samples in our analysis indicate modern water and thus recent recharge at all depths, other radioactive tracers such as tritium or ${ }^{14} \mathrm{C}$ are needed to determine the age of water, which was not done in our work. In addition, to test the conceptual aquifer model at $\mathrm{EC}$ and to better comprehend flow routes and interconnectedness in the wells, long-term time and depth discrete monitoring of isotopic samples would be required.

\section{Conclusions}

This research examined the development of Bengaluru's groundwater table during the last few decades. The trends in borewell drilling depth can be divided into three phases: pre-2000, when deeper drilling began, 2000-2010, when massive deeper drilling occurred, and 2010-2020, when a slow fading out of deeper drilling was observed, with no discernible trend in the southern and municipal areas due to improved infrastructure. Our findings show that borewell depth has strongly increased, while water yields remain similar, indicating the unsustainability of drilling deeper wells. Camera inspections confirmed that water levels in the wells are solely determined by rock fractures, not by well depth. The results of the waters' isotope signatures support this conceptual model and suggest that all groundwater pumped in the Bengaluru region is recently recharged. However, considering the increase in drilling depths, current recharge may not provide for the long-term groundwater sustainability of this aquifer. Recursive and continuous monitoring of groundwater levels and sampling for isotopes, as well as the monitoring of all factors related to anthropogenic groundwater usage, would be necessary to identify local groundwater recharge processes as a base for sustainable groundwater management.

Supplementary Materials: The following are available online at https: / www.mdpi.com/article / 10.3390/su132112149/su132112149/s1, Primary Survey Well Depths, Camera Well Logs, Isotope Depths.

Author Contributions: Conceptualization, T.K. and M.G.; data curation, T.K., C.M.K. and V.K.; funding acquisition, M.G. and A.B.; investigation, T.K. and C.M.K.; methodology, T.K. and M.G.; supervision, M.G.; visualization, T.K.; writing-original draft, T.K.; writing-review and editing, M.G. and A.B. All authors have read and agreed to the published version of the manuscript.

Funding: Financing from the Research Unit FOR2432 "Social-Ecological Systems in the Indian RuralUrban Interface: Functions, Scales, and Dynamics of Transition" funded by the German Research Foundation (DFG, grant number 279374797) is gratefully acknowledged. This project was also supported by the Graduate Program BangaDyn: Rural-urban Dynamics in Bengaluru, funded by University of Kassel.

Data Availability Statement: The videos of the camera inspections used in this study are available from the corresponding author upon reasonable request.

Acknowledgments: We gratefully acknowledge Veena Srinivasan, Ashoka Trust, for Research in Ecology and Environment (ATREE), Bangalore, and K.N. Ganeshaiah (UASB, GKVK Campus) and Mudalagiriyappa Zars (UASB, GKVK Campus) for constructive discussions and access to secondary data. We also thank Rama N.S. and Ravindra Singh (ELCITA) for providing access to the wells in EC for camera inspections and sampling. We thank the ATREE field team for the assistance in borewell sampling in the UAC. We thank Deeksha and Moksha (KC) for compiling the primary data, Santosh L.G. (KC) for discussions, and Narayana and Manjunath (KC) for assistance in field work.

Conflicts of Interest: The authors declare no conflict of interest. 


\section{Appendix A}

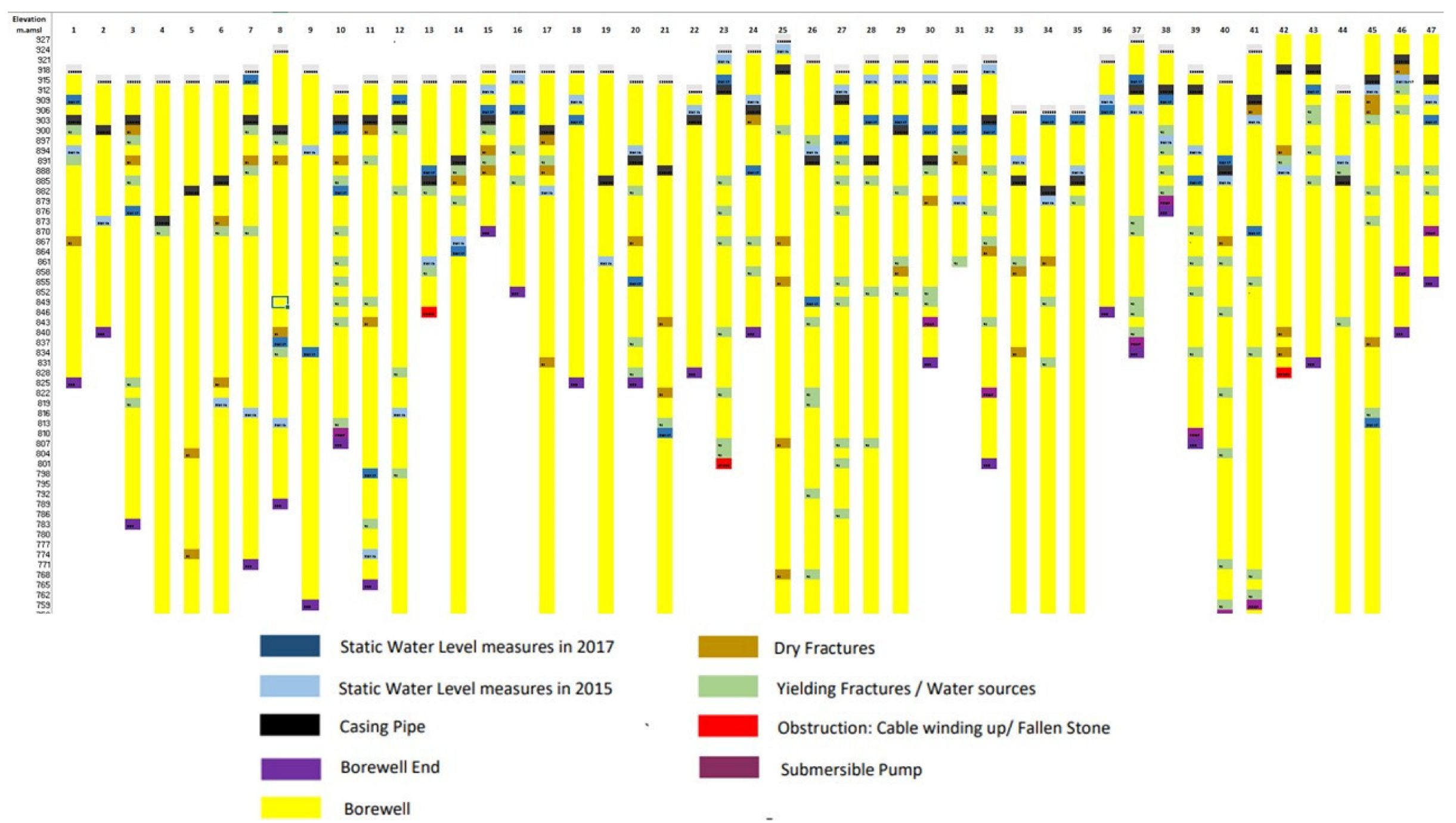

Figure A1. Logs of camera-inspected wells in EC. 


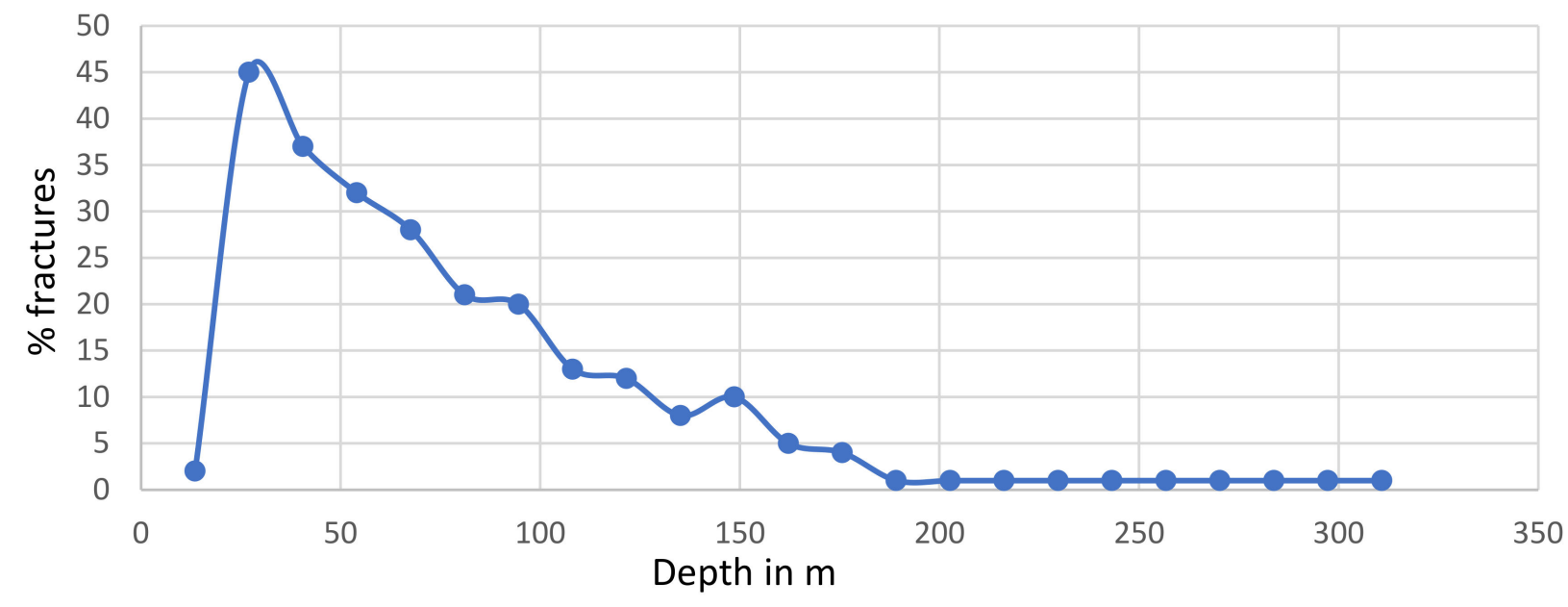

Figure A2. Percentage fractures v/s depth in wells of EC noted through camera inspection. Note that fracture density is highest between 30 and $120 \mathrm{~m}$ and drastically reduces at deeper depths.

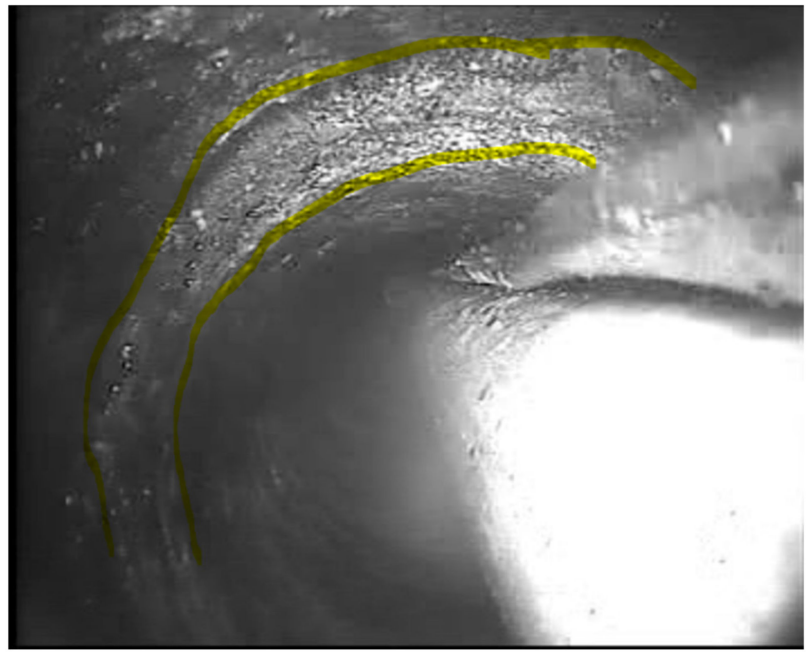

(a)

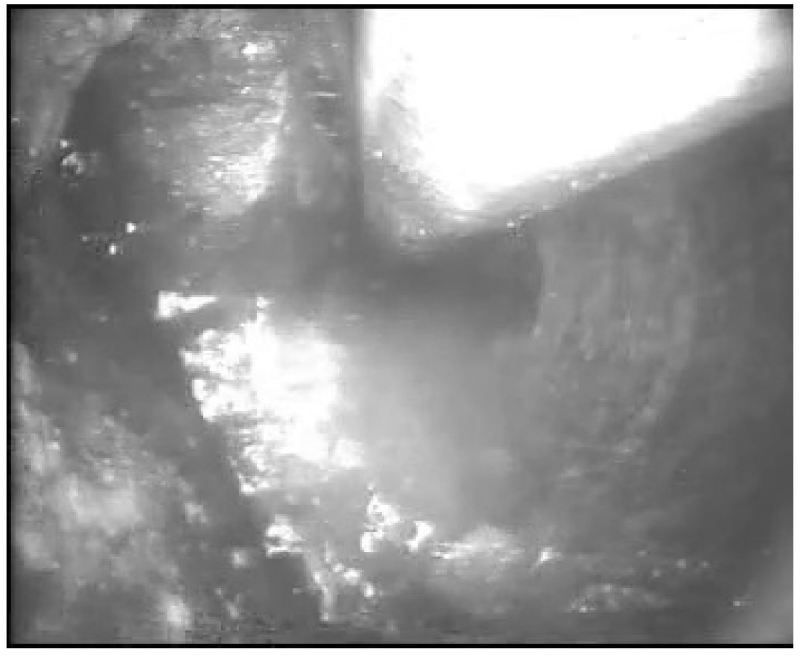

(b)

Figure A3. Pictures of dry fractures (a) and yielding fractures (b) in the camera-inspected wells in EC. 


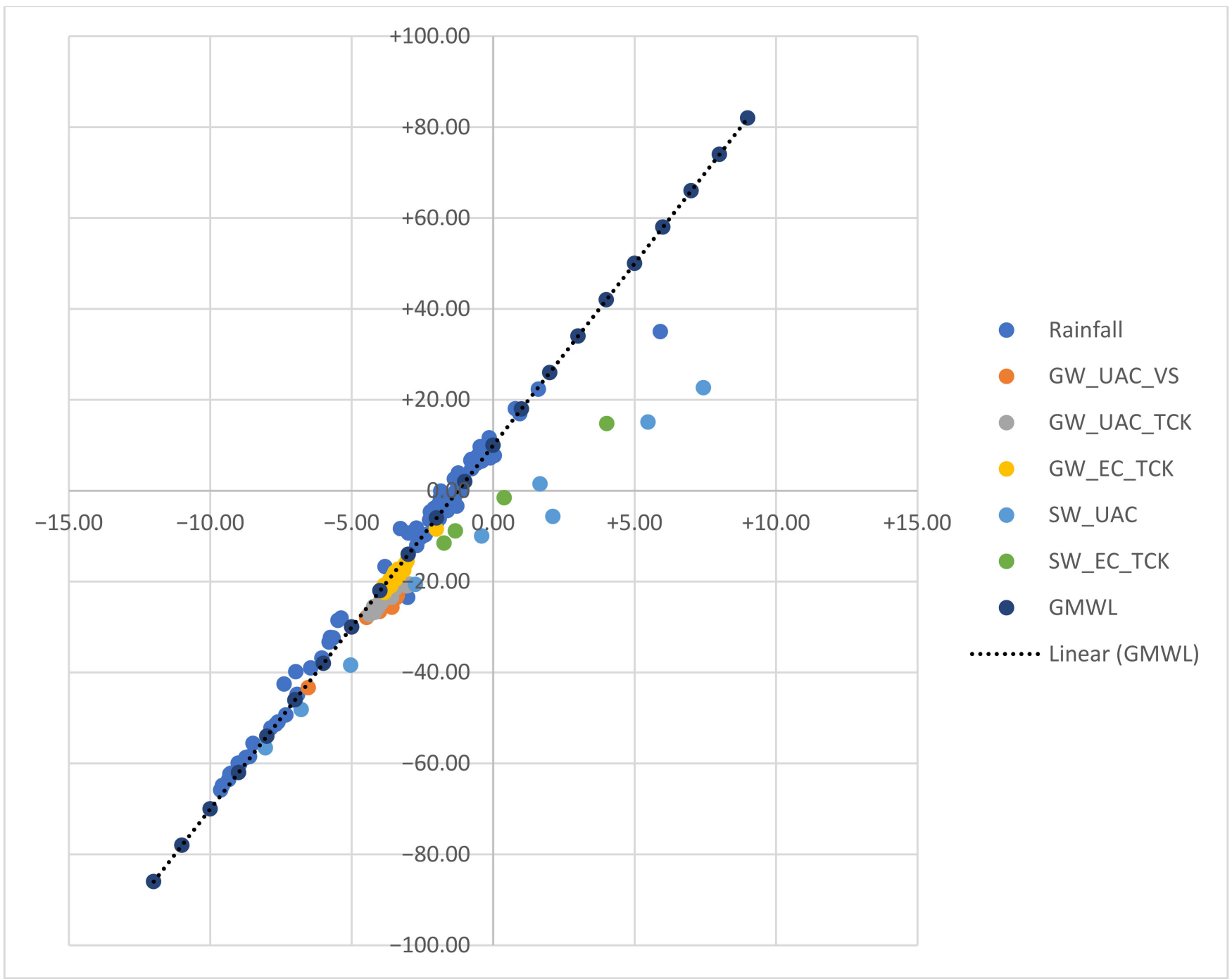

Figure A4. Dual isotope plot of samples from UAC (agricultural LU) and EC (industrial LU). Note there is no significant difference in isotopic concentration indicating recent recharge in wells at all depths in both catchments. 
Table A1. Details of inspected wells and selections for further monitoring.

\begin{tabular}{|c|c|c|c|c|c|c|c|c|c|c|c|c|}
\hline Well No. & LAT & LON & Elevation & Catchment & Depth (m) & Well Type & $\begin{array}{l}\text { Yielding Fractures } \\
\text { below } 245 \mathrm{~m}\end{array}$ & $\begin{array}{c}\text { SWL } 2016 \\
\text { m.bgl }\end{array}$ & $\begin{array}{c}\text { SWL } 2017 \\
\text { m.bgl }\end{array}$ & d_18O & $\mathrm{d} \_2 \mathrm{H}$ & $\begin{array}{c}\text { Selection for } \\
\text { Further } \\
\text { Monitoring }\end{array}$ \\
\hline 1 & 12.84056 & 77.66333 & 918.02 & EC & 90.09 & A & - & 9.9 & 23.4 & -3.61 & -20.94 & No \\
\hline 2 & 12.84667 & 77.65944 & 914.11 & $\mathrm{EC}$ & 75.08 & $\mathrm{~A}$ & - & - & 42.0 & -3.79 & -21.54 & No \\
\hline 3 & 12.85028 & 77.65778 & 915.92 & $\mathrm{EC}$ & 132.13 & B & - & 39.0 & 0.0 & - & - & $\mathrm{No}$ \\
\hline 4 & 12.85222 & 77.65861 & 915.62 & $\mathrm{EC}$ & 390.39 & C & - & - & 287.1 & -3.83 & -21.43 & No \\
\hline 6 & 12.85278 & 77.65972 & 915.62 & $\mathrm{EC}$ & 300.30 & C & $256 \mathrm{~m}$ & 212.0 & 95.1 & -3.84 & -21.58 & Yes \\
\hline 7 & 12.84361 & 77.66222 & 919.22 & $\mathrm{EC}$ & 75.08 & $\mathrm{~A}$ & - & 4.5 & 101.8 & -3.71 & -20.81 & No \\
\hline 8 & 12.84722 & 77.65972 & 924.62 & $\mathrm{EC}$ & 135.14 & B & - & 88.6 & 111.1 & -3.82 & -22.05 & No \\
\hline 9 & 12.84306 & 77.66278 & 918.62 & $\mathrm{EC}$ & 159.16 & B & - & 84.1 & 22.6 & -3.66 & -19.69 & No \\
\hline 10 & 12.84306 & 77.66444 & 913.81 & $\mathrm{EC}$ & 104.20 & A & - & 13.5 & 28.8 & -3.81 & -21.39 & No \\
\hline 11 & 12.84389 & 77.66333 & 915.92 & EC & 150.15 & B & - & 118.6 & 142.3 & -3.29 & -17.31 & No \\
\hline 13 & 12.84444 & 77.66611 & 914.41 & EC & $\mathrm{NA}$ & - & - & 25.5 & 52.3 & -3.88 & -21.20 & No \\
\hline 14 & 12.84444 & 77.66611 & 914.71 & EC & 210.21 & B & - & 49.5 & 46.8 & -3.47 & -17.94 & No \\
\hline 15 & 12.84583 & 77.66778 & 918.02 & $\mathrm{EC}$ & 45.05 & A & - & 11.4 & 5.0 & -3.54 & -19.04 & No \\
\hline 16 & 12.84667 & 77.66639 & 918.02 & EC & 63.06 & A & - & 9.6 & 3.0 & -3.35 & -17.24 & No \\
\hline 17 & 12.84694 & 77.66972 & 917.12 & $\mathrm{EC}$ & 390.39 & $\mathrm{C}$ & - & 235.7 & 36.0 & -3.41 & -17.77 & No \\
\hline 18 & 12.84667 & 77.66917 & 918.02 & EC & 90.09 & B & - & 15.0 & 9.0 & -3.25 & -17.08 & No \\
\hline 19 & 12.84722 & 77.66889 & 918.62 & EC & 330.33 & $\mathrm{C}$ & - & 249.8 & 55.0 & -3.54 & -18.76 & No \\
\hline 20 & 12.84639 & 77.67028 & 915.32 & $\mathrm{EC}$ & 87.69 & A & - & 60.1 & 19.8 & -3.39 & -17.78 & No \\
\hline 21 & 12.84639 & 77.67056 & 914.11 & $\mathrm{EC}$ & 317.42 & $\mathrm{C}$ & - & 101.5 & 0.0 & - & - & No \\
\hline 22 & 12.84583 & 77.67056 & 913.21 & $\mathrm{EC}$ & 84.08 & A & - & & 5.1 & -2.01 & -8.47 & No \\
\hline 23 & 12.83639 & 77.65778 & 924.02 & $\mathrm{EC}$ & $\mathrm{NA}$ & - & - & 7.5 & 2.3 & -3.30 & -17.77 & No \\
\hline 24 & 12.83694 & 77.66028 & 924.62 & $\mathrm{EC}$ & 84.08 & A & - & 36.0 & 14.4 & -3.44 & -19.49 & No \\
\hline
\end{tabular}


Table A1. Cont.

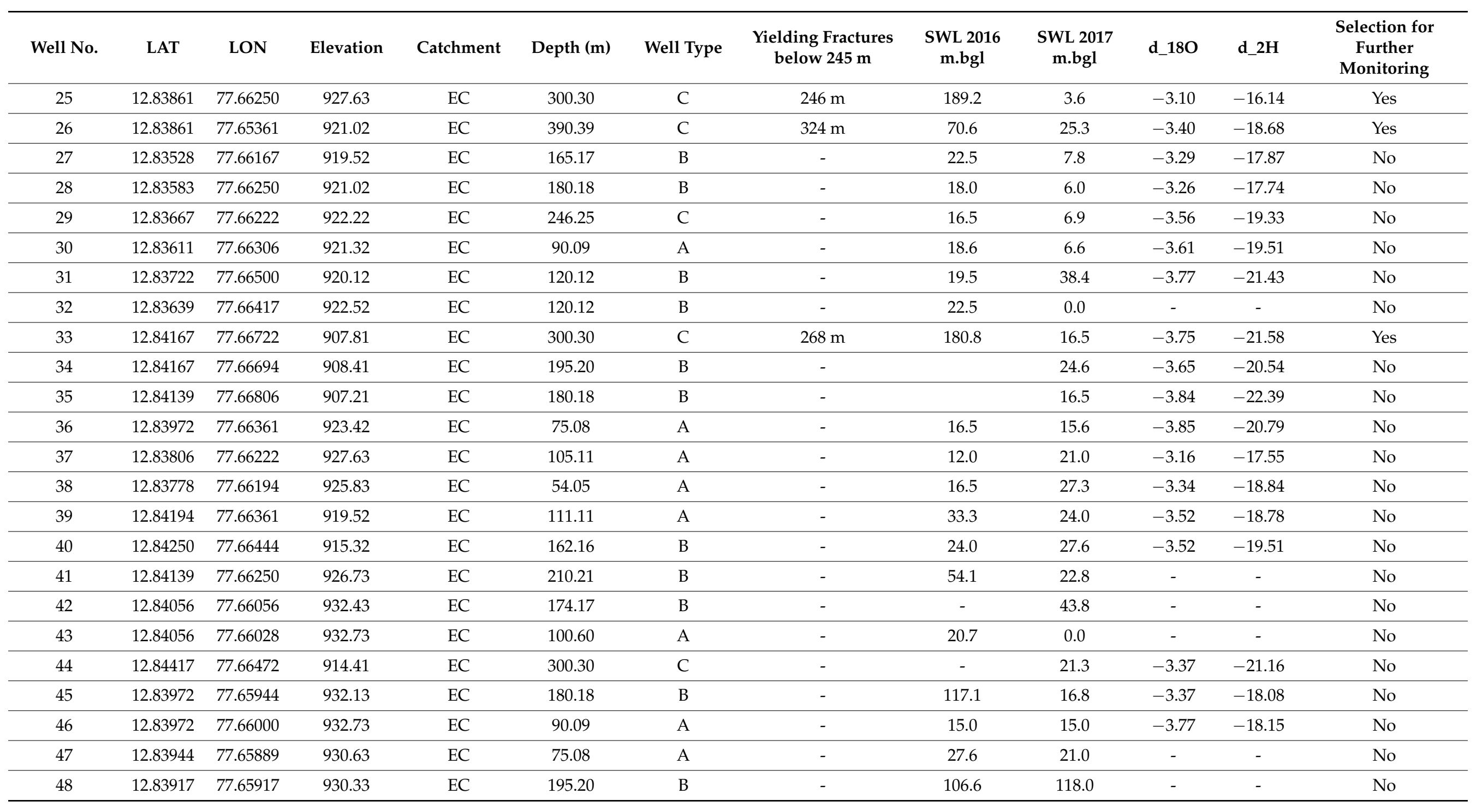


Table A1. Cont.

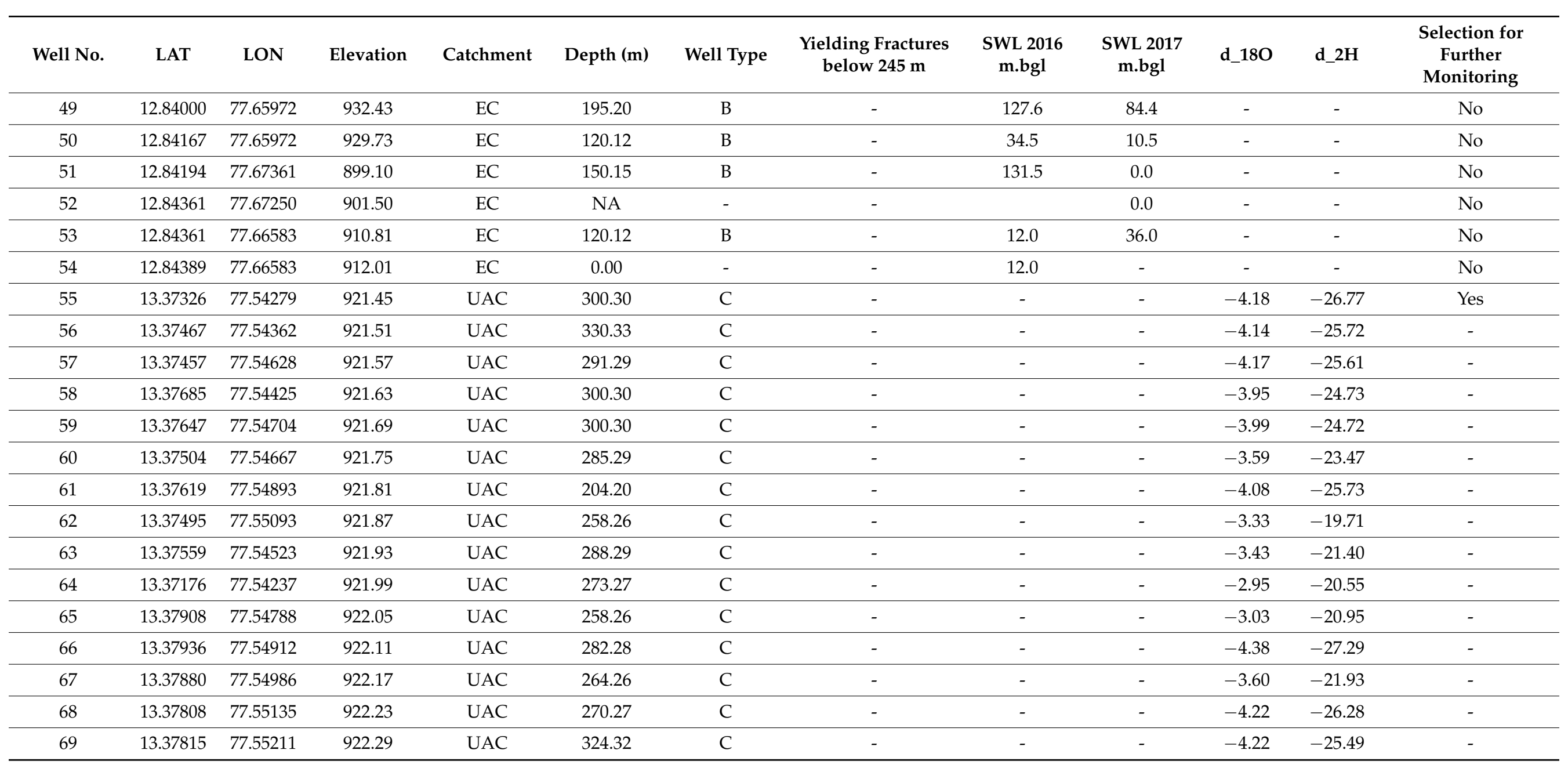




\section{References}

1. McDonald, R.I.; Weber, K.; Padowski, J.; Flörke, M.; Schneider, C.; Green, P.A.; Gleeson, T.; Eckman, S.; Lehner, B.; Balk, D.; et al. Water on an Urban Planet: Urbanization and the Reach of Urban Water Infrastructure. Glob. Environ. Change 2014, $27,96-105$. [CrossRef]

2. Flörke, M.; Schneider, C.; McDonald, R.I. Water Competition between Cities and Agriculture Driven by Climate Change and Urban Growth. Nat. Sustain. 2018, 1, 51-58. [CrossRef]

3. Schwartz, F.W.; Liu, G.; Yu, Z. HESS Opinions: The Myth of Groundwater Sustainability in Asia. Hydrol. Earth Syst. Sci. 2020, 24, 489-500. [CrossRef]

4. Gleeson, T.; Cuthbert, M.; Ferguson, G.; Perrone, D. Global Groundwater Sustainability, Resources, and Systems in the Anthropocene. Annu. Rev. Earth Planet. Sci. 2020, 48, 431-463. [CrossRef]

5. Bredehoeft, J.D. The Water Budget Myth Revisited: Why Hydrogeologists Model. Ground Water 2002, 40, 340-345. [CrossRef] [PubMed]

6. Ferguson, G.; Cuthbert, M.O.; Befus, K.; Gleeson, T.; McIntosh, J.C. Rethinking Groundwater Age. Nat. Geosci. 2020, 13, 592-594. [CrossRef]

7. Shah, T. Taming the Anarchy—Groundwater Governance in South Asia; Resources for the Future: Washington, USA, 2009; ISBN 978-1-933115-60-3.

8. Groundwater of South Asia; Mukherjee, A. (Ed.) Springer: Singapore, 2018; ISBN 978-981-10-3888-4.

9. Kulkarni, H.; Shankar, P.; Vijay, S. Groundwater Resources in India: An Arena for Diverse Competition. Local Environ. 2014, 19, 990-1011. [CrossRef]

10. Shankar, P.V.; Kulkarni, H.; Krishnan, S. India's Groundwater Challenge and the Way Forward. Econ. Polit. Wkly. 2011, 46, 37-45.

11. Kulkarni, H.; Shah, M.; Vijay Shankar, P.S. Shaping the Contours of Groundwater Governance in India. J. Hydrol. Reg. Stud. 2015, 4, 172-192. [CrossRef]

12. Arshad, I.; Umar, R. Status of Urban Hydrogeology Research with Emphasis on India. Hydrogeol. J. 2020, 28, 477-490. [CrossRef]

13. Das, S. Frontiers of Hard Rock Hydrogeology in India. In Ground Water Development-Issues and Sustainable Solutions; Ray, S.P.S., Ed.; Springer: Singapore, 2019; ISBN 9789811317705.

14. Srinivasan, V.; Thompson, S.; Madhyastha, K.; Penny, G.; Jeremiah, K.; Lele, S. Why Is the Arkavathy River Drying? A Multiple-Hypothesis Approach in a Data-Scarce Region. Hydrol. Earth Syst. Sci. 2015, 19, 1905-1917. [CrossRef]

15. Sudhira, H.S.; Ramachandra, T.V.; Subrahmanya, M.H.B. Bangalore. Cities 2007, 24, 379-390. [CrossRef]

16. Raj, K. Urbanization and Water Supply: An Analysis of Unreliable Water Supply in Bangalore City, India. In Nature, Economy and Society; Ghosh, N., Mukhopadhyay, P., Shah, A., Panda, M., Eds.; Springer: New Delhi, India, 2016; ISBN 978-81-322-2403-7.

17. Patil, V.S.; Thomas, B.K.; Lele, S.; Eswar, M.; Srinivasan, V. Adapting or Chasing Water? Crop Choice and Farmers' Responses to Water Stress in Peri-Urban Bangalore, India. Irrig. Drain. 2019, 68, 140-151. [CrossRef]

18. Steinhübel, L.; Wegmann, J.; Mußhoff, O. Digging Deep and Running Dry-the Adoption of Borewell Technology in the Face of Climate Change and Urbanization. Agric. Econ. 2020, 51, 685-706. [CrossRef]

19. Hora, T.; Srinivasan, V.; Basu, N.B. The Groundwater Recovery Paradox in South India. Geophys. Res. Lett. 2019, 46, 9602-9611. [CrossRef]

20. Ballukraya, P.N.; Srinivasan, V. Sharp Variations in Groundwater Levels at the Same Location: A Case Study from Heavily Exploited, Fractured Rock Aquifer System near Bangalore, South India. Curr. Sci. 2019, 117, 130-138. [CrossRef]

21. Thippiah, P. Water and environmental crisis in mega city: Vanishing lakes and over-exploited ground water in Bangalore. In Urban Governance in Karnataka and Bengaluru: Global Changes and Local Impacts; Cambridge Scholars: Newcastle upon Tyne, UK, 2009.

22. Chandra, S.; Auken, E.; Maurya, P.K.; Ahmed, S.; Verma, S.K. Large Scale Mapping of Fractures and Groundwater Pathways in Crystalline Hardrock By AEM. Sci. Rep. 2019, 9, 398. [CrossRef] [PubMed]

23. Saha, D.; Marwaha, S.; Dwivedi, S.N. National Aquifer Mapping and Management Programme: A Step Towards Water Security in India. In Water Governance: Challenges and Prospects; Singh, A., Saha, D., Tyagi, A.C., Eds.; Springer: Singapore, 2019; pp. 49-66. ISBN 9789811326998.

24. Sekhar, M.; Mujumdar, P.P. Evaluation of Scheme of Ground Water Management E Regulation (2012-17); Department of Civil Engineering, Indian Institute of Scoences: Bangalore, India, 2017.

25. Rangan, A.K. Participatory Groundwater Management: Lessons from Programmes Across India. IIM Kozhikode Soc. Manag. Rev. 2016, 5, 8-15. [CrossRef]

26. Ghose, B.; Dhawan, H.; Kulkarni, H.; Aslekar, U.; Patil, S.; Ramachandrudu, M.V.; Cheela, B.; Jadeja, Y.; Thankar, B.; Chopra, R.; et al. Peoples' Participation for Sustainable Groundwater Management. In Clean and Sustainable Groundwater in India; Saha, D., Marwaha, S., Mukherjee, A., Eds.; Springer: Singapore, 2018; ISBN 978-981-10-4551-6.

27. Collins, S.L.; Loveless, S.E.; Muddu, S.; Buvaneshwari, S.; Palamakumbura, R.N.; Krabbendam, M.; Lapworth, D.J.; Jackson, C.R.; Gooddy, D.C.; Nara, S.N.V.; et al. Groundwater Connectivity of a Sheared Gneiss Aquifer in the Cauvery River Basin, India. Hydrogeol. J. 2020, 28, 1371-1388. [CrossRef]

28. Srinivasan, V. Doing Science That Matters to Address India's Water Crisis. Resonance 2017, 22, 303-313. [CrossRef] 
29. Hynds, P.; Regan, S.; Andrade, L.; Mooney, S.; O’Malley, K.; DiPelino, S.; O’Dwyer, J. Muddy Waters: Refining the Way Forward for the "Sustainability Science" of Socio-Hydrogeology. Water 2018, 10, 1111. [CrossRef]

30. Hoffmann, E.; Jose, M.; Nölke, N.; Möckel, T. Construction and Use of a Simple Index of Urbanisation in the Rural-Urban Interface of Bangalore, India. Sustainability 2017, 9, 2146. [CrossRef]

31. Wegmann, J.; Mußhoff, O. Groundwater Management Institutions in the Face of Rapid Urbanization - Results of a Framed Field Experiment in Bengaluru, India. Ecol. Econ. 2019, 166, 106432. [CrossRef]

32. Sekhar, M.; Tomer, S.; Thiyaku, S.; Giriraj, P.; Murthy, S.; Mehta, V. Groundwater Level Dynamics in Bengaluru City, India. Sustainability 2018, 10, 26. [CrossRef]

33. Hirsch, R.M.; Slack, J.R. A Nonparametric Trend Test for Seasonal Data With Serial Dependence. Water Resour. Res. 1984, 20, 727-732. [CrossRef]

34. Mitas, L.; Mitasova, H. Spatial Interpolation. In Geographical Information Systems: Principles, Techniques, Management and Applications; Wiley: Chichester, UK, 1999.

35. Van Dijk, M.P. Government Policies with Respect to an Information Technology Cluster in Bangalore, India. Eur. J. Dev. Res. 2003, 15, 93-108. [CrossRef]

36. Heitzman, J. Corporate Strategy and Planning in the Science City: Bangalore as "Silicon Valley". Econ. Polit. Wkly. 2021, 34, 11.

37. Bala Subrahmanya, M.H. Innovation and Growth of Engineering SMEs in Bangalore: Why Do Only Some Innovate and Only Some Grow Faster? J. Eng. Technol. Manag. 2015, 36, 24-40. [CrossRef]

38. Maechler, M.; Rosseeuw, P.; Struyf, A.; Hubert, M.; Hornik, K. Cluster: Cluster Analysis Basics and Extensions; R Foundation: Vienna, Austria, 2021.

39. Deshpande, R.D. Isotope Tracer Applications in Groundwater Hydrology: A Review of Indian Scenario. In Groundwater of South Asia; Mukherjee, A., Ed.; Springer: Singapore, 2018; pp. 233-245. ISBN 978-981-10-3888-4.

40. Gupta, S.K.; Deshpande, R.D. Groundwater Isotopic Investigations in India: What Has Been Learned? Curr. Sci. 2005, 89, 12.

41. Penny, G.; Srinivasan, V.; Apoorva, R.; Jeremiah, K.; Peschel, J.; Young, S.; Thompson, S. A Process-based Approach to Attribution of Historical Streamflow Decline in a Data-scarce and Human-dominated Watershed. Hydrol. Process. 2020, 34, 1981-1995. [CrossRef]

42. Dansgaard, W. Stable Isotopes in Precipitation. Tellus 1964, 16, 436-468. [CrossRef]

43. Kumar, B.; Rai, S.P.; Kumar, U.S.; Verma, S.K.; Garg, P.; Kumar, S.V.V.; Jaiswal, R.; Purendra, B.K.; Kumar, S.R.; Pande, N.G. Isotopic Characteristics of Indian Precipitation. Water Resour. Res. 2010, 46, W12548. [CrossRef]

44. Goldman, M.; Narayan, D. Water Crisis through the Analytic of Urban Transformation: An Analysis of Bangalore's Hydrosocial Regimes. Water Int. 2019, 44, 95-114. [CrossRef]

45. Tomer, S.K.; Sekhar, M.; Balakrishnan, K.; Malghan, D.; Thiyaku, S.; Gautam, M.; Mehta, V.K. A Model-Based Estimate of the Groundwater Budget and Associated Uncertainties in Bengaluru, India. Urban Water J. 2020, 18, 1-11. [CrossRef]

46. Kumar, A.; Ramachandran, P. Cross-Sectional Study of Factors Influencing the Residential Water Demand in Bangalore. Urban Water J. 2019, 16, 171-182. [CrossRef]

47. Castán Broto, V.; Sudhira, H.S.; Unnikrishnan, H. Walk the Pipeline: Urban Infrastructure Landscapes in Bengaluru's Long Twentieth Century. Int. J. Urban Reg. Res. 2021, 45, 696-715. [CrossRef]

48. Mehta, V.K.; Goswami, R.; Kemp-Benedict, E.; Malghan, D.; Muddu, S. Social Ecology of Domestic Water Use in Bangalore. Econ. Polit. Wkly. 2013, 48, 12.

49. Yadav, B.; Gupta, P.K.; Patidar, N.; Himanshu, S.K. Ensemble Modelling Framework for Groundwater Level Prediction in Urban Areas of India. Sci. Total Environ. 2020, 712, 135539. [CrossRef] [PubMed]

50. Chandrakanth, M.G. Water Resource Economics; Springer: New Delhi, India, 2015; ISBN 978-81-322-2478-5.

51. Siddique, I.; Mahamuni, K.; Desai, J.; Patil, S.; Kulkarni, H. Hydrogeological Aspects of Paticipatory Aquifer Mapping (PAQM) in Urban Groundwater Scenario in South-East Bengaluru; Advanced Center for Water Resources Development and Management (ACWADAM): Bangalore, India, 2017; p. 79.

52. Ramya, C. The Indian Megacity Digging a Million Wells, BBC 2020. Available online: https://www.bbc.com/future/article/2020 1006-india-why-bangalore-is-digging-a-million-wells (accessed on 30 October 2021).

53. Rahul, P.; Ghosh, P. Long Term Observations on Stable Isotope Ratios in Rainwater Samples from Twin Stations over Southern India; Identifying the Role of Amount Effect, Moisture Source and Rainout during the Dual Monsoons. Clim. Dyn. 2019, 52, 6893-6907. [CrossRef]

54. Kumar, S.; Sharma, S.; Navada, S.V.; Deodhar, A.S. Environmental Isotopes Investigation on Recharge Processes and Hydrodynamics of the Coastal Sedimentary Aquifers of Tiruvadanai, Tamilnadu State, India. J. Hydrol. 2009, 364, 23-39. [CrossRef]

55. Wenninger, J. Handbook for Stable Isotope Data Interpretation in India; IHE Delft Institute for Water Education: Delft, The Netherlands, 2020.

56. Singh, M.J.; Davis, D.; Somashekar, R.K.; Prakash, K.L.; Shivanna, K. Environmental Isotopes Investigation in Groundwater of Challaghatta Valley, Bangalore: A Case Study. Afr. J. Environ. Sci. Technol. 2010, 4, 226-233.

57. Ramesh, M. The Climate Solution. India's Climate-Change Crisis and What We Can Do about It; Hachette: Gurugram, India, 2018; ISBN 978-93-5195-232-9. 